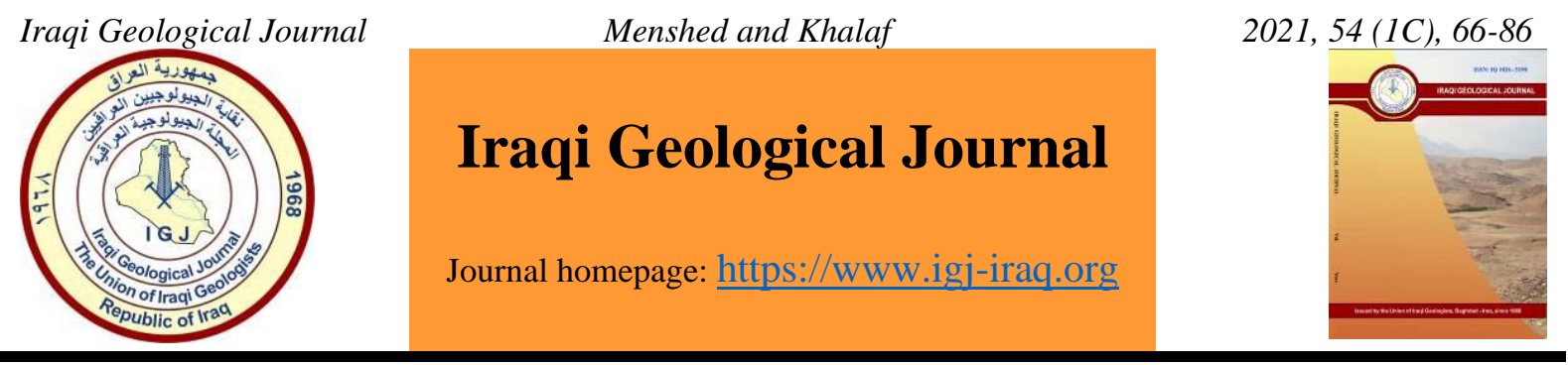

\title{
Geological Modeling for Nahr Umr Formation in Subba Oil Field, Southern Iraq
}

\author{
Mahdi Ali Menshed ${ }^{1}$ and Huda Daaj Khalaf ${ }^{2, *}$ \\ ${ }^{1}$ Department of Geology, College of Science, University of Thi-Qar, Thi-Qar, Iraq \\ ${ }^{2}$ Department of Reservoir Management, Thi-Qar Oil Company, Thi-Qar, Iraq \\ *Correspondence: E-mail: hudadaaj99@yahoo.com
}

Received: 29 September 2020; Accepted:1 January 2021; Published: 31 March 2021

\begin{abstract}
Geological modeling is very important in reservoir study, where it is described the framework of the structure and provided a distribution of petrophysical properties, the geological model helps to comprehend the fluid flow behaviour affected by heterogeneity of reservoir, also it is used to calculate oil initially in place and to choose the new well location in reservoir management. In this study, a geological model is built for Nahr Umr Formation based on data of 11 wells (SU-2, SU-3, SU-4, SU-5, SU-6, SU-7, SU-9, SU-10, SU-11, SU-13, and SU-14), including the location of wells, well tops, also contour map of the Nahr Umr Formation in Subba oil field is utilized. The structural model is constructed for the Nahr Umr Formation, which consists of two domes. The formation is composed of sandstone mainly interbedded with shale. The formation is divided into four units (B1, $\mathrm{B} 2, \mathrm{C} 1$, and $\mathrm{C} 2$ ) depending on well log data, each unit is divided into layers for getting better distribution of petrophysical properties, where unit B2 is divided to the number of layers is higher than other units due to its heterogeneity. Variogram is used as a geostatistical method to predict the petrophysical properties at unsampled locations, experimental variogram is calculated from well log data in a horizontal and vertical direction. The spherical variogram model shows a good fitting with the experimental variogram. Sequential Gaussian algorithm is used in distribution of petrophysical properties in a geological model which shows good petrophysical properties in unit $\mathrm{B} 2$ and unit $\mathrm{B} 1$, while units $\mathrm{C} 1$ and $\mathrm{C} 2$ are highly saturated with water.
\end{abstract}

Keywords: Geological modeling; Nahr Umr Formation; Geostatistical analysis; Depositional environment

\section{Introduction}

Geological modeling provides the distribution of petrophysical properties such as permeability, porosity and net pay, it is considered the basis on which the reservoir model is constructed. Building a geological model requires many data including structure map, porosity, water saturation, oil water contact, net to gross thickness (Chen, 2007). Representing the geological features is very important in overall reservoir characterization. There are many reasons for utilizing stochastic simulation techniques to get geological features or petrophysical distribution of static model, the reasons including, difficulty in capturing structure variable with the spatial position, direction, and incomplete information about feature of structure. Several simulation methods are used to achieve geological description, one of the most popular methods is Gaussian simulation which is applied to build geological description (Qiu and Kelkar, 1995).

DOI: $\underline{10.46717 / i g j .54 .1 C .6 M s-2021-03-26}$ 
The proper estimation of the spatial distribution of petrophysical properties is considered curtail task because the correct calculation and reservoir development rely on it (Viera et al. 2017). Alghanemy and Mahdi (2020) explain the distribution of effective porosity and water saturation using the 2D cross section in two directions at the upper parts anticline of Majnoon field, as well Faisal and Mahdi (2020) employ the same model in Badra oilfield. Several researchers were interested in studying the reservoir oil fields using geostatistical analysis and variogram, among the important researches in this field are: Sahin et al. (1998) used the sequential Gaussian and kriging simulation to get maps for porosity and permeability in carbonate reservoir, eastern Suadi Arabia. They applied cross-validation in the generated modeling.

Amanipoor et al., (2013) use static modeling to analyze properties of Bangestan oil reservoir. They employed the petrophysical data to prepare the 3D model, and variogram to specify the spatial correlation. Kouoh and Dicoum (2019) study the porosity of Douala oil field in Ghana by geostatistical modeling. They re-sampled porous data by interpolation techniques, using the Gaussian model to simulate the anisotropy of the data and they interpolated variogram and fitted by the least squares method. Abraham et al., (2019) built static models for estimate reservoir performance evolution (case study, Cameroon). They distribute the parameters of the reservoir to build 2D static models and to describe variation of the reservoir using the experimental semivariogram in different directaaions. Rahimi and Riahi (2020) employ the statistics model to estimate and optimizing the strategies of the Sarvak Formation.

According to the previous study (Zabeel, 2017), the Nahr Umr Formation in Subba field is divided into three parts depends on lithology types and well logs interpretation. The lower part of the formation consists of small sand bodies intertwined with shale, silt, and thin beds of carbonates. The thickness of this part is ranging from (1-13.5) $\mathrm{m}$ and it is represented the shallow marine deposits. The middle part of the formation represents with thickness sandy rock unit where the high marine regressive and predominance of clastic river deposits. The thickness of this part is estimated from (110.5 - 148.5) $\mathrm{m}$. It consists of more than one sandy sedimentary cycle with well-rounded and sorting sand as well as containing a large amount of Quartz arenite. The size of the grains increases upwards with the presence of the cross-bedding structures and the traces of the plants at the top of each sedimentary cycle.

This sandy part is permeated with a little silt in some parts. This unit represents clean beach sand dunes because sand is exposed to the action of the winds and the movement of the tides. The upper part of the Nahr Umr Formation, there are two types of sedimentary sequence, the first succession is coarsing upwards, by grading mud rocks alluvial mud rocks to sandy rocks and vice versa for the second sequence. The thickness of this part is ranging (86-112) $\mathrm{m}$. This sequence assume that the sediments were deposited through the sea level fall and growth of the delta. This part contains high oil saturation within the sand units. The purpose of geological modeling is to evaluate the petrophysical properties in the reservoir in order to estimate oil initially in place and provide useful information in developing oil field and the reservoir simulation studies.

\section{Study Area}

Subba oil field is situated in the southern of Iraq, about $12 \mathrm{~km}$ to Luhais oil field (Fig.1). The dimensions of the field are $7 \mathrm{~km}$ and $30 \mathrm{~km}$ long. It consists of two domes separated by saddle. The small dome locates in the north while the large dome locates in the south. The Nahr Umr Formation is one of the main reservoirs in the field. The formation thickness is about $221 \mathrm{~m}$, it is composed mainly of sandstone rocks overlapped with shale and Alluvial rocks in the upper part of the formation which characterized by good reservoir properties. 


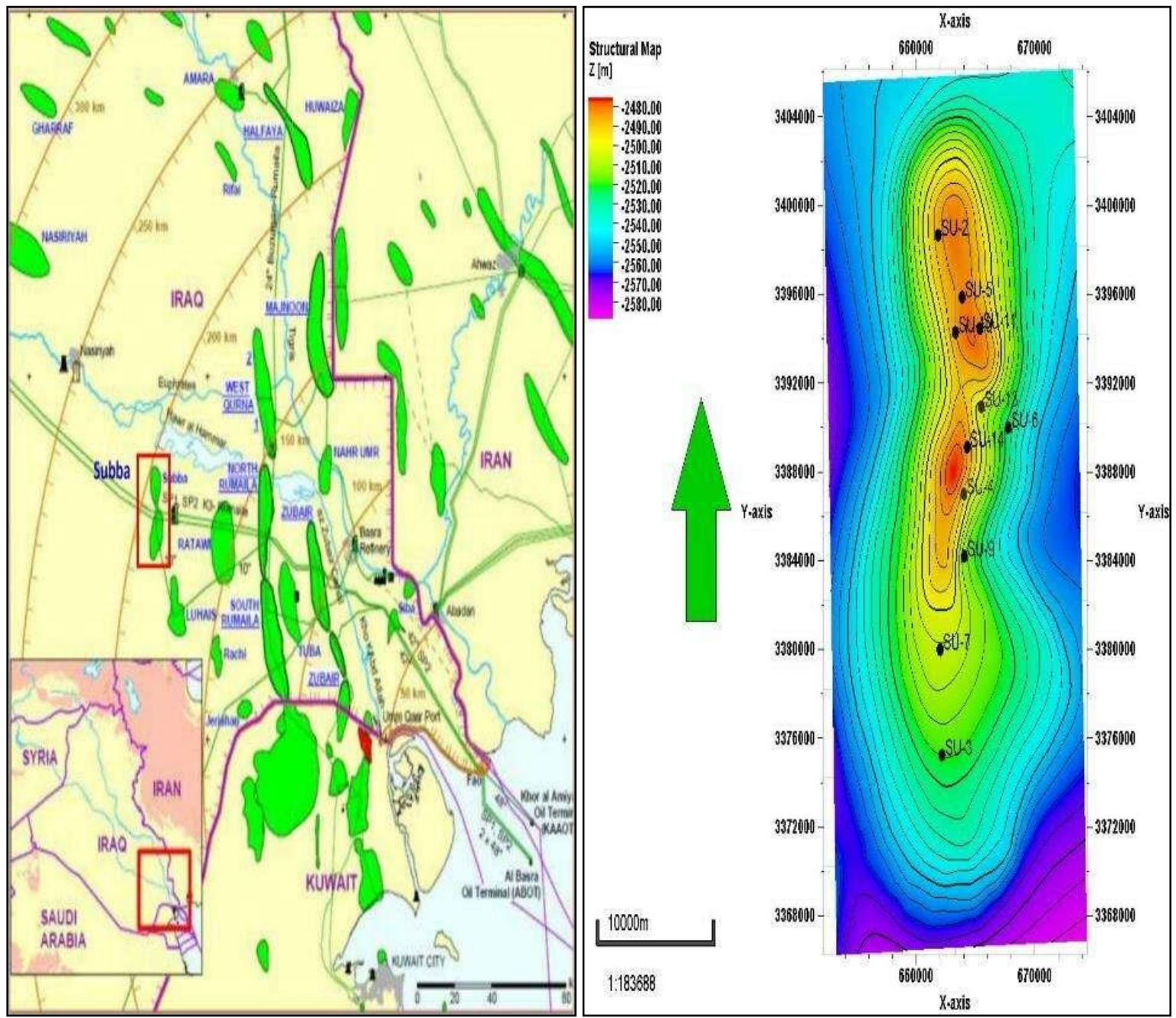

Fig. 1. Location of Subba oilfield in SE of Iraq (NOC, 1979) (left side), and structural contour map of the top Nahr Umr Formation (right side)

\section{Depositional Environment}

Nahr Umr Formation deposited during Early Cretaceous period and it is considered as one of the main reservoirs in the southern of Iraq and neighboring regions (Al-Khazraji and Shuker 2015). The stratigraphic column of the Nahr Umr Formation of an Albian clastic unit characterized by the massive clean basal sands which are overlain by a mixture of silt, shale and massive clean sand interbeds. There are two types of sandstone Tidal and fluvial sand (Jaber and Shuker, 2014). The stratigraphic column is shown in Fig.2. According to the Al-Dabbas et al. (2012) multi-depositional environments were recognized, prodelta, distal bar, distributary channels, over bank and tidal flat as in Fig. 3. The upper part of the formation is characterized by fining upwards sediments and interlaminations of carbonate, shale and sandstone which indicate the tidal channels deposits influenced of near shore, shallow open marine and the middle and upper parts of the formation are mainly of fluvial and delta with the influence of the inner shelf environment. The basal deltaic platform is characterized by massive clean sands deposited by a series of migrating and amalgamating channels. Thin silts and shales commonly occur at the top of the channel sand packages. The evolution from the deltaic marginal continental setting, to the shallow marine barrier setting came in response to collapse of the continental margin, and sea level rise. 


\begin{tabular}{|c|c|c|c|c|c|}
\hline PERIOD & EPOCH & \multirow{2}{*}{$\begin{array}{l}\begin{array}{c}\text { FORMATION } \\
\text { NAME }\end{array} \\
\text { Dibdibba }\end{array}$} & \multirow{2}{*}{$\begin{array}{c}\begin{array}{c}\text { DEPTH } \\
\mathrm{m}\end{array} \\
107 \\
\end{array}$} & \multirow{2}{*}{$\begin{array}{l}\text { LITHOLOGY } \\
\because \sim: \sim \sim ?\end{array}$} & \multirow{2}{*}{ 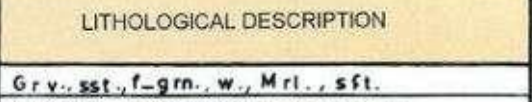 } \\
\hline \multirow{5}{*}{ 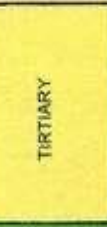 } & \multirow{2}{*}{ 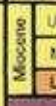 } & & & & \\
\hline & & Lower Fars & 197 & $\approx \wedge \approx \wedge \approx$ & Mrl, srt, w. Anhd sity, hd, mass. \\
\hline & $2 \sqrt{\text { Lawer }}$ & Ghar & 278 & & Grytsst. \\
\hline & \multirow{2}{*}{$\frac{8}{8} \times \frac{8}{8}$} & Dammam & \multicolumn{2}{|l|}{493.5} & Dol., md., hd_xin, por, Vug., anhd. \\
\hline & & Rus & 646.5 & $\mp \hat{\wedge} \wedge \hat{\imath}$ & Anhd, stt., mass., w., striks of Dol. \\
\hline \multirow{15}{*}{$\begin{array}{l}0 \\
\frac{2}{0} \\
\frac{1}{0} \\
\frac{8}{4} \\
\frac{4}{2} \\
\frac{11}{2}\end{array}$} & \multirow{9}{*}{$\frac{2}{2}$} & $\begin{array}{l}\text { Umm Er } \\
\text { Raduma }\end{array}$ & 1088 & & Dol., slty_hd., xin arg., vug., anhd. \\
\hline & & Tayarat & 1298 & & Dol-, md-hdxin. arg , anhd. \\
\hline & & Shiranish & 1479.5 & & Lst, sft, xin., mri., slty, dol. \\
\hline & & Hartha & 1742.5 & & $\begin{array}{l}\text { Lst., md-hd, xin., dol., chk., anhd. } \\
\text { w., sh., slty-hd., fiss., cale. }\end{array}$ \\
\hline & & Sodi & \multirow{2}{*}{$\frac{1934.8}{\frac{1999.5}{3038}}$} & & Lst., $m d_{-h d,}$ xin., comp., arg., ch $k, m r l$. \\
\hline & & $\begin{array}{l}\text { Tanuma } \\
\text { Rhasib }\end{array}$ & & $\approx$ & 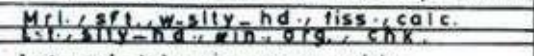 \\
\hline & & Mishrif & 2150 & 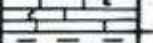 & Lst_md_hd., xin., arg., chk. \\
\hline & & Rumaila & 2242 & $\overline{1} \bar{\varepsilon}=1$ & Lst., md-hd, xin., chk. w. sh. sity fiss \\
\hline & & Ahmadi & 2363 & $\overline{-} \sim \bar{z}$ & $\begin{array}{l}\text { Sh-sity hid, fiss . calc, ww, mrl. } \\
\text { strks of Lst, md-nd.., xin., }\end{array}$ \\
\hline & \multirow{6}{*}{$\frac{1}{0}$} & Mauddud & 2457.5 & 18 & Lst, , md - hd., xin., chk, arg., cale \\
\hline & & $\begin{array}{l}\text { Nohr Umr } \\
\text { Shuaiba }\end{array}$ & $\frac{2678.5}{2748}$ & 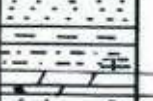 & S., st., f-md., gin., cale, w., sh., sity-hd, frss \\
\hline & & Zubair & 3191.5 & 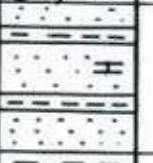 & $\begin{array}{l}\text { Sh., sity-hd., fiss, pyr., w., sst, f., } \\
\text { grn., frib., cale., w., bil. }\end{array}$ \\
\hline & & Ratawi & 3404.5 & $\begin{array}{l}-1--1 \\
-1=1 \\
-1-1\end{array}$ & 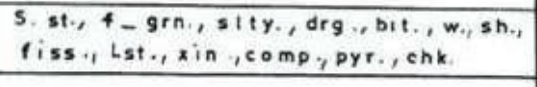 \\
\hline & & \multirow{2}{*}{$\begin{array}{l}\text { Yamama } \\
\text { Sulaiy }\end{array}$} & \multirow{2}{*}{$\begin{array}{l}3707 \\
\sin 5\end{array}$} & 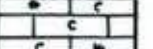 & \\
\hline & & & & i 1101 & $\begin{array}{l}\text { Lst., md-hd, } x \text { in., pyr, chk., gle, foss. } \\
\text { Let., md-hd. xin. org.,pyr. }\end{array}$ \\
\hline
\end{tabular}

Fig. 2. Stratigraphic column for Subba oilfield (EOC, 2014)

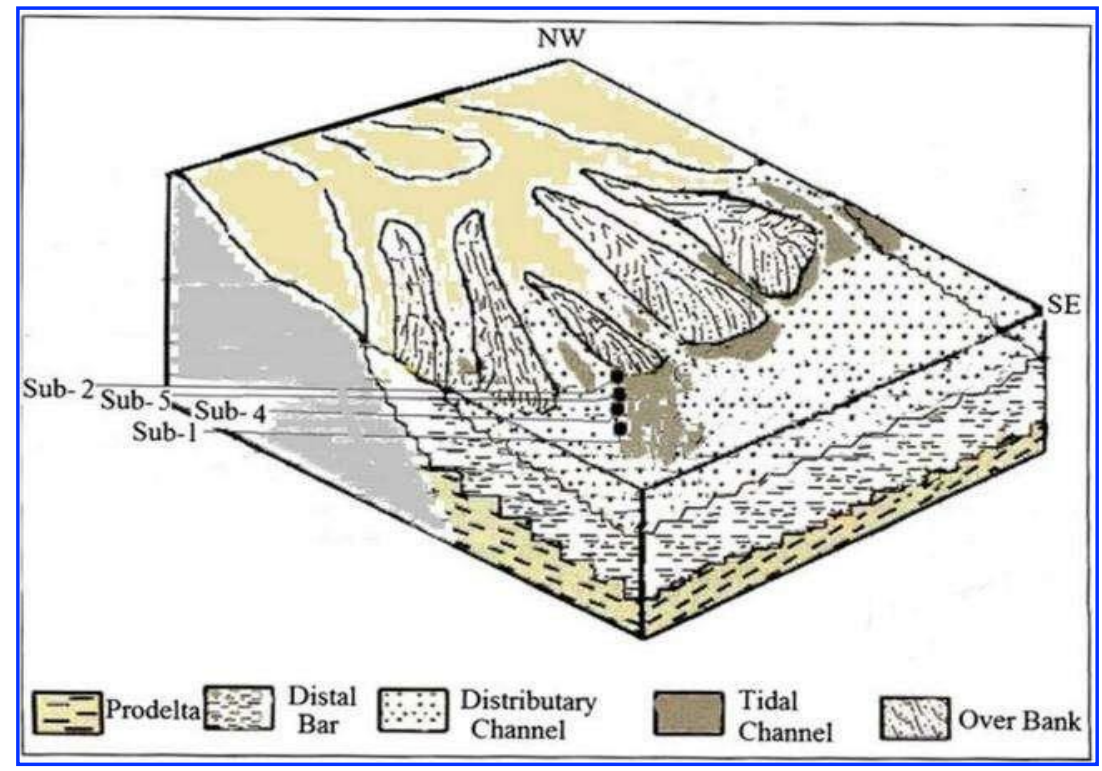

Fig. 3. Schematic NW-SE block diagram showing the proposed depositional model for the microfacies of Nahr Umr Formation (Note: the boreholes locations are not according to scale) (Al-Dabbas et al. 2012) 
The barrier island complex comprises an elongate sand barrier (forming parallel to the paleo coastline), and associated back barrier tidal flats. Tidal flat back barrier deposits recognized in Subba Nahr Umr drape off the landward side (west) of the barrier. The development of such a clastic barrier system is related to wave energy, tidal range, sediment supply and coastal morphology. An idealized tidal flat shallowing upwards sequence comprises a fining upwards clastic tidal flat facies succession made up of subtidal and tidal channels, intertidal sand, mixed and mud flats, and supratidal salt marshes Fig.4. Although the complete facies succession rarely appears within the Nahr Umr reservoir interval due to erosion and non- deposition, all tidal flat facies have been identified in the back-barrier region in Subba (Anadarko, 2009).

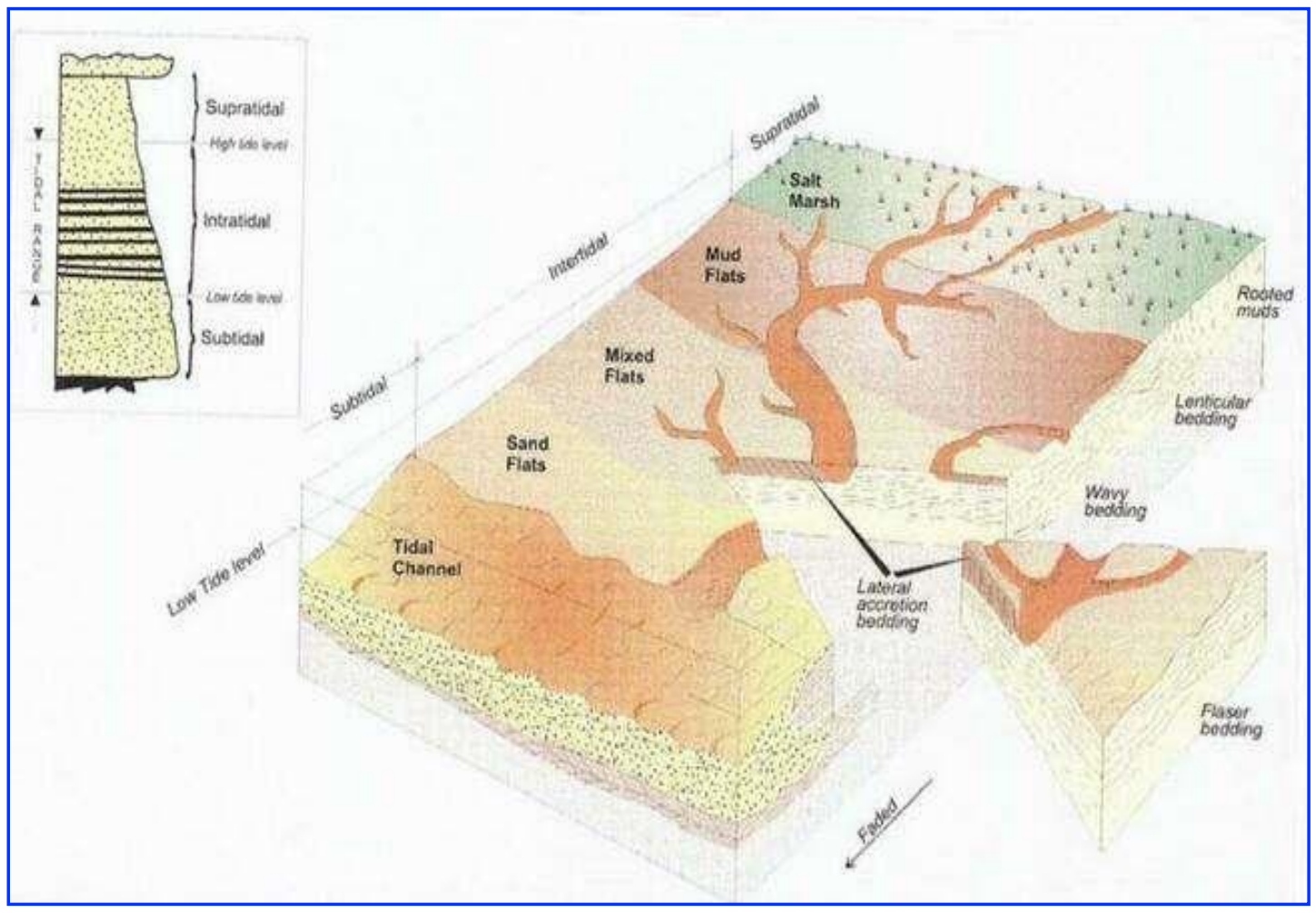

Fig. 4. Tidal flat environment with an idealized regressive succession (modified after Walker and Jemes 1992)

\section{Materials and Methods}

The data are collected from computer processed interpretation achieved by South Oil Company (2008), these data include:

Well data: comprises wellheads (locations of wells), CPI (computered processed interpretation of well logs and well tops. Seismic data: including the structure map. Constructing geological model requires the following steps:

\subsection{Import Data}

\subsubsection{Well Correlation}

After well data is imported to the simulator, well correlation for the Nahr Umr Formation is carried out. Well correlation is applied as an easy method for giving an idea and allowing visualization in properties (water saturation and porosity) and thickness (Nasser et al. 2017). Two sections of well correlation are chosen to show variation in the thickness of the reservoir. Fig.5 shows the location of well correlation, Fig.6 and Fig.7 show well correlation of lithological units of Nahr Umr Formation located in the vertical section and horizontal section respectively. 


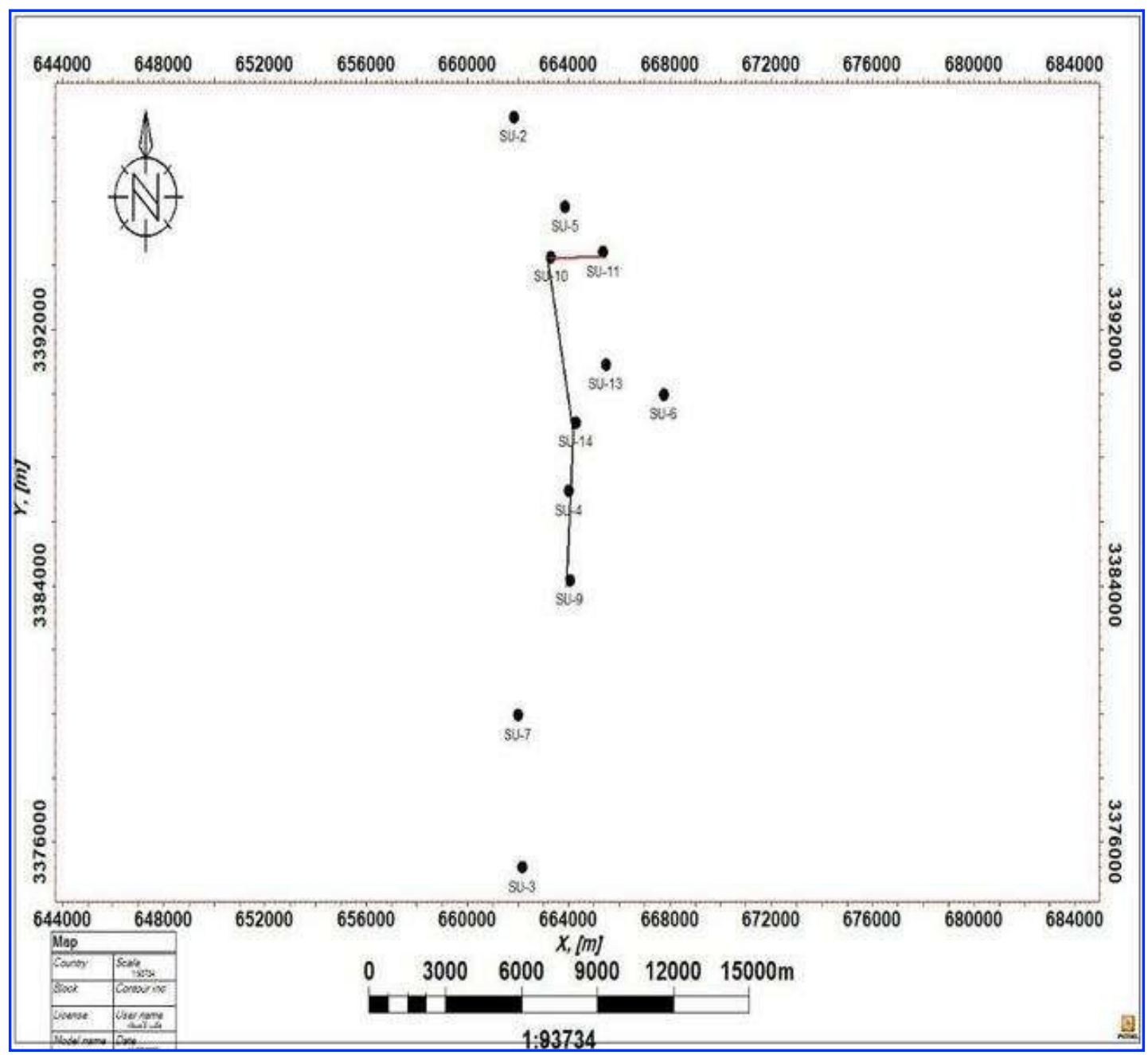

Fig. 5. Location of well correlation

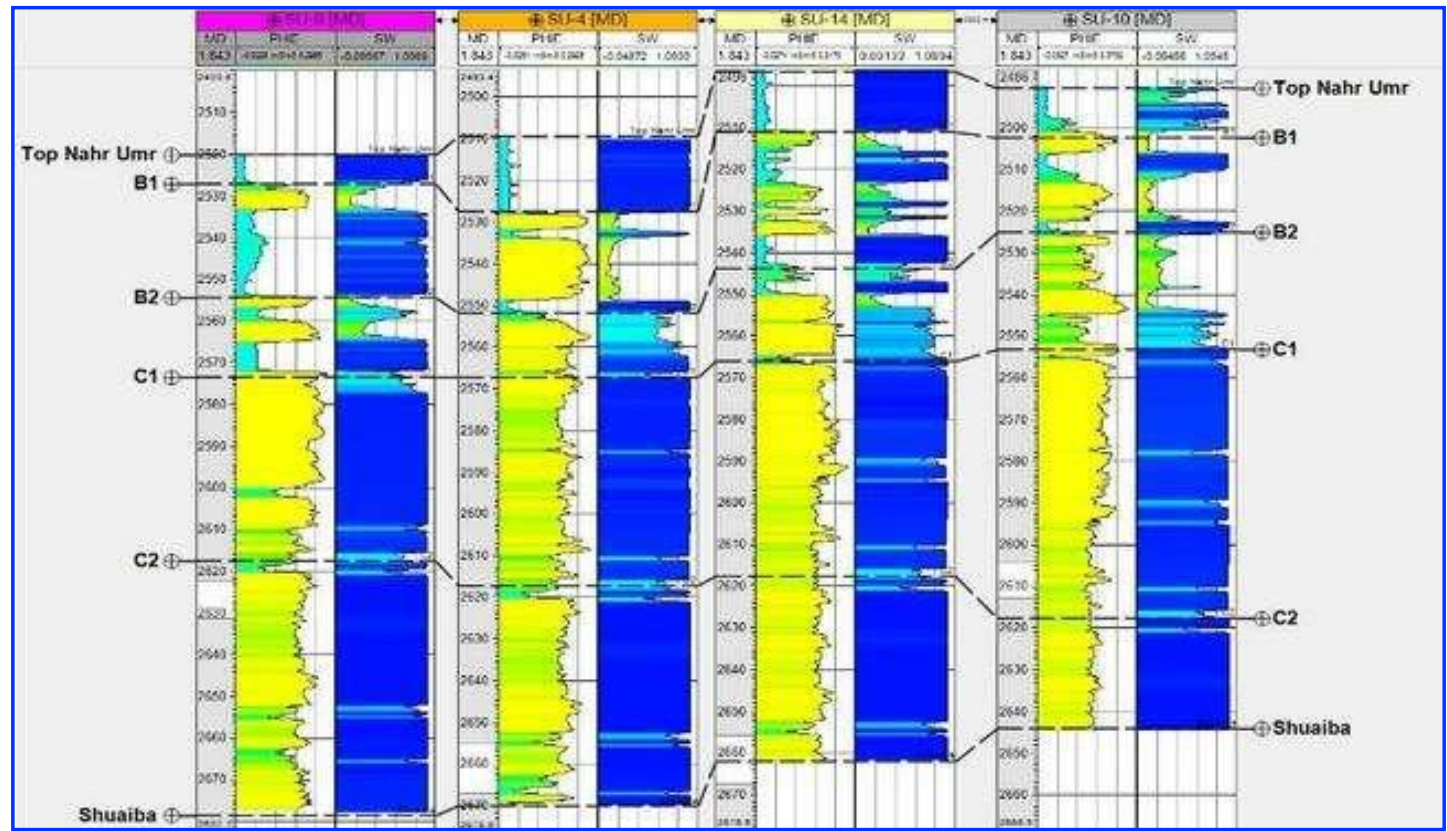

Fig. 6. Well correlation for Nahr Umr units located in the vertical section 


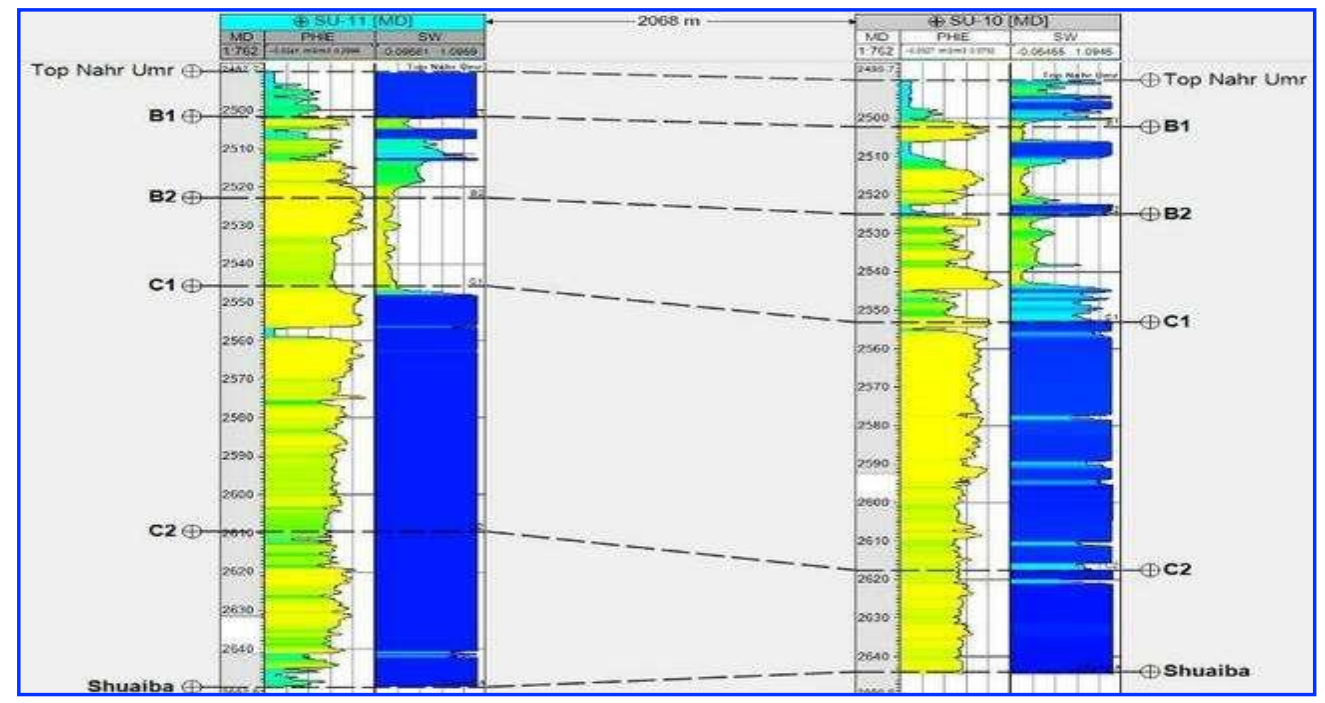

Fig. 7. Well correlation for Nahr Umr units located in the horizontal section

\subsubsection{Structural modeling}

Structural model represents the first step in construction geological model using seismic including surface depth map and fault. It is constructed from depth converted seismic and faults data to create framework of the reservoir and incorporated with the internal reservoir layering. The framework must capture the large-scale heterogeneities affecting the fluid flow in the reservoir such as unconformities or faults (Cannon, 2018). In this study the structural contour map of the Nahr Umr Formation is used to build structural model after digitizing it.

\subsubsection{Structural Contour Map}

The structural map of top Nahr Umr Formation after digitizing is imported to the simulator, and the structural maps of the other units can be constructed depending on information of well tops. Fig. 8 shows structural maps of Nahr Umr Formation units, which indicates that the structure consists of two domes separated by saddle.

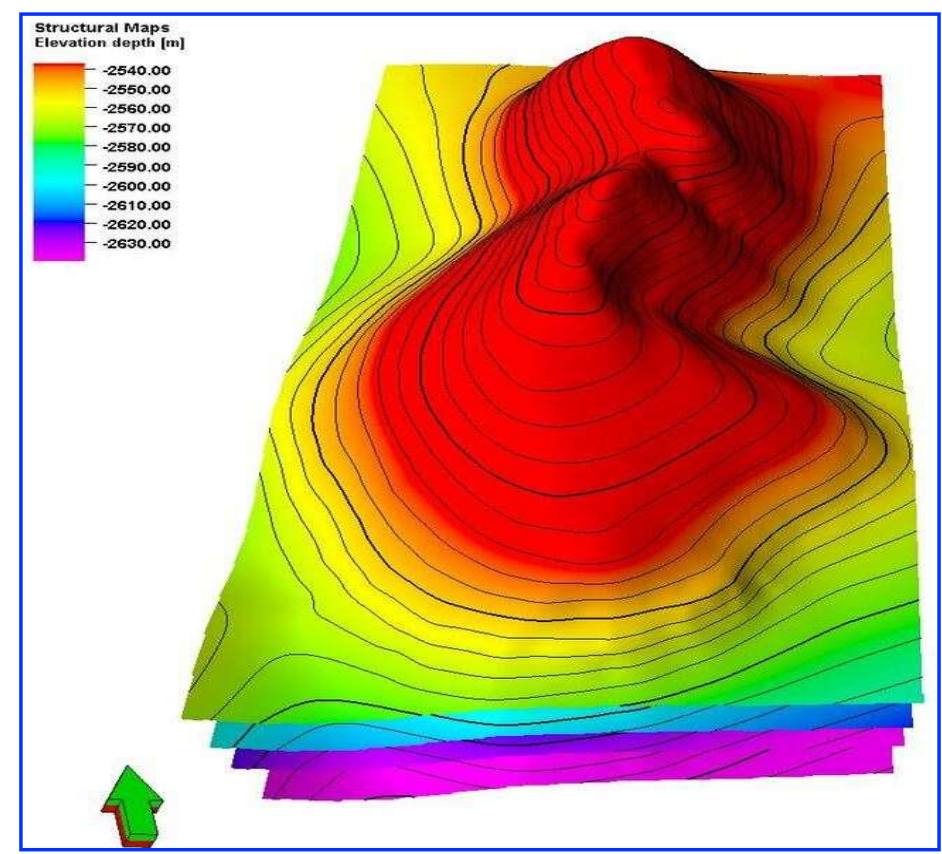

Fig. 8. Structural maps of the Nahr Umr Formation units (B1, B2, C1, and C2) 


\subsubsection{Layering}

Layering is additional subdivision of the zone to get better distribution of petrophysical properties (Schlumberger, 2013). Each unit in the Nahr Umr formation is divided into layers depending on petrophysical properties and thickness. Number of layers for each unit Number of layers for each unit are: 10 layers for unit B1, 20 layers for unit B2, 8 layers for unit $\mathrm{C} 1$, and 8 layers for unit $\mathrm{C} 2$. The total of layers is 46 .

\subsubsection{Grid system}

The aim of imposing the grid on the reservoir is to permit us to solve the equations of nonlinear flow that estimate the response of the reservoir to variation at the wells or boundaries (Jreou, 2013). The reservoir model is divided to 3D geocelluar network. Each cell has one value of petrophysical properties. The dimensions of each cell are important in the model accuracy, in this study, the Nahr Umr Formation was represented by a three-dimensional grid system $(147 \times 265 \times 46)$ in $(\mathrm{I}, \mathrm{J}$ and $\mathrm{K})$ direction, where the grid dimensions are $150 \mathrm{~m}$ in width and $150 \mathrm{~m}$ in length and the total number of cells is 1791930.

\subsubsection{Scale up well log}

It is an averaging method to give one value of property for each cell, there are many statistical methods utilized to scale up well logs such as harmonic, arithmetic, and geometric method (Altameemi and Alzaidy, 2018). Arithmetic averaging method are used to scale up well log of porosity and water saturation.

\subsubsection{Geostatistical analysis}

Geostatistics is useful tool applied to different scientific field, it is combined with classical statistics, this aims for increasing the knowledge over the dataset to quantify and identify the spatial structure and to know the spatial continuity (Vendrusculo et al. 2004). It is considered one of the most techniques utilized effectively in the simulation a reservoir characterization. Geostatistics is a way for estimation the petrophysical properties at unsampled location using spatial correlation (Pyrcz and Deutsch, 2014). Geostatistical analysis includes many steps (variogram map, transformation data, and variogram fitting).

\subsubsection{Variogram map}

Variogram is a geostatistical method utilized widely for spatial correlation of variability of permeability, facies, porosity, and other petrophysical properties and geological data to calculate the properties at unsampled location (Ezekwe, 2010). Variogram is determined in the number of directions and distances. The variogram map is used to determine the direction of continuity, where the main aim of variogram map to determine major and minor directions which represents the horizontal direction, the minor direction is perpendicular on major direction, while the vertical direction is perpendicular to the horizontal direction. 2D variogram map of Nahr Umr Formation defines the direction of sample points is shown in Fig. 9. The major and minor directions of the variogram analysis are based on the 2D variogram map and vertical direction are shown in Fig. 10. Fig.9 shows variogram map which is utilized to calculate the variogram in a number of distances and direction, 2D variogram map used to determine continuity in horizontal direction, this direction posted on map represents the major direction. 


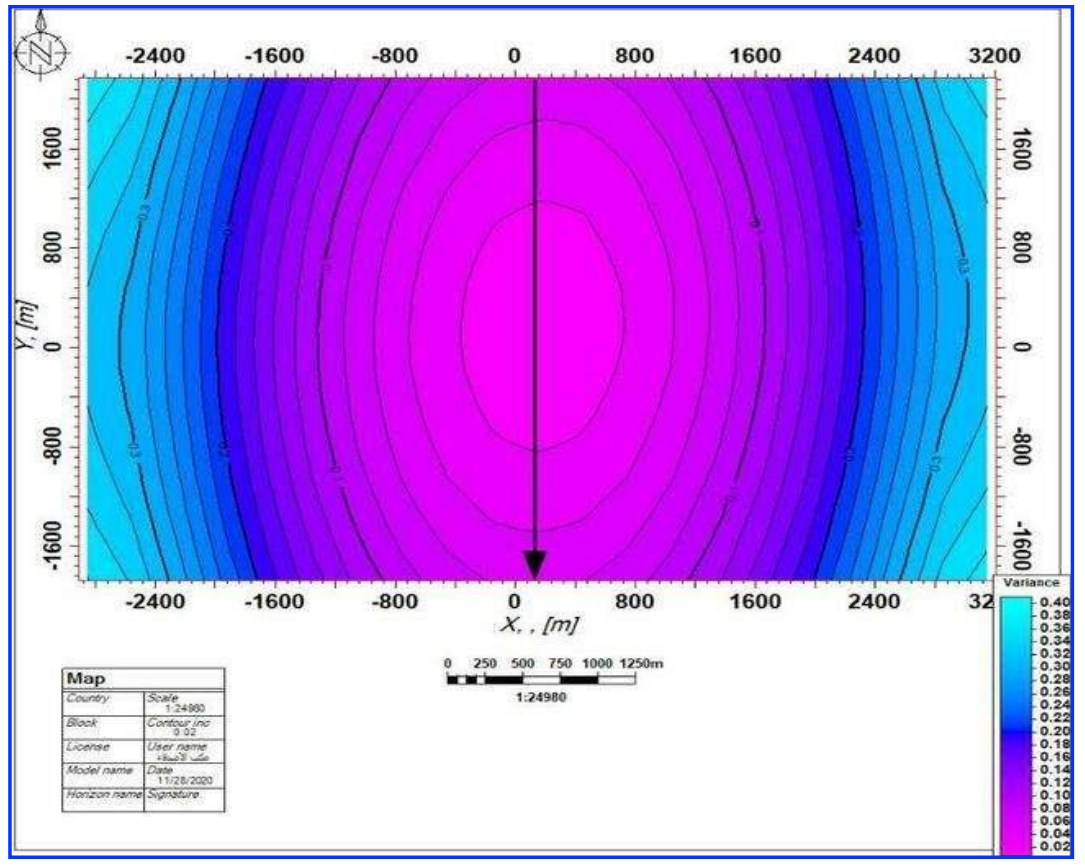

Fig. 9. 2D variogram map

Variogram is used as a statistical method to predict the properties at unsampled location by correlation between two pairs of samples at a certain distance and direction, since the properties variance with direction and distance so, it is important to select the directions to predict properties. The experimental variogram uses the samples of available data to predict the property at unsampled location in horizontal and vertical direction, where horizontal direction represents the major direction and minor direction which is perpendicular to major direction, while vertical direction represents the depth as shown in Fig.10.

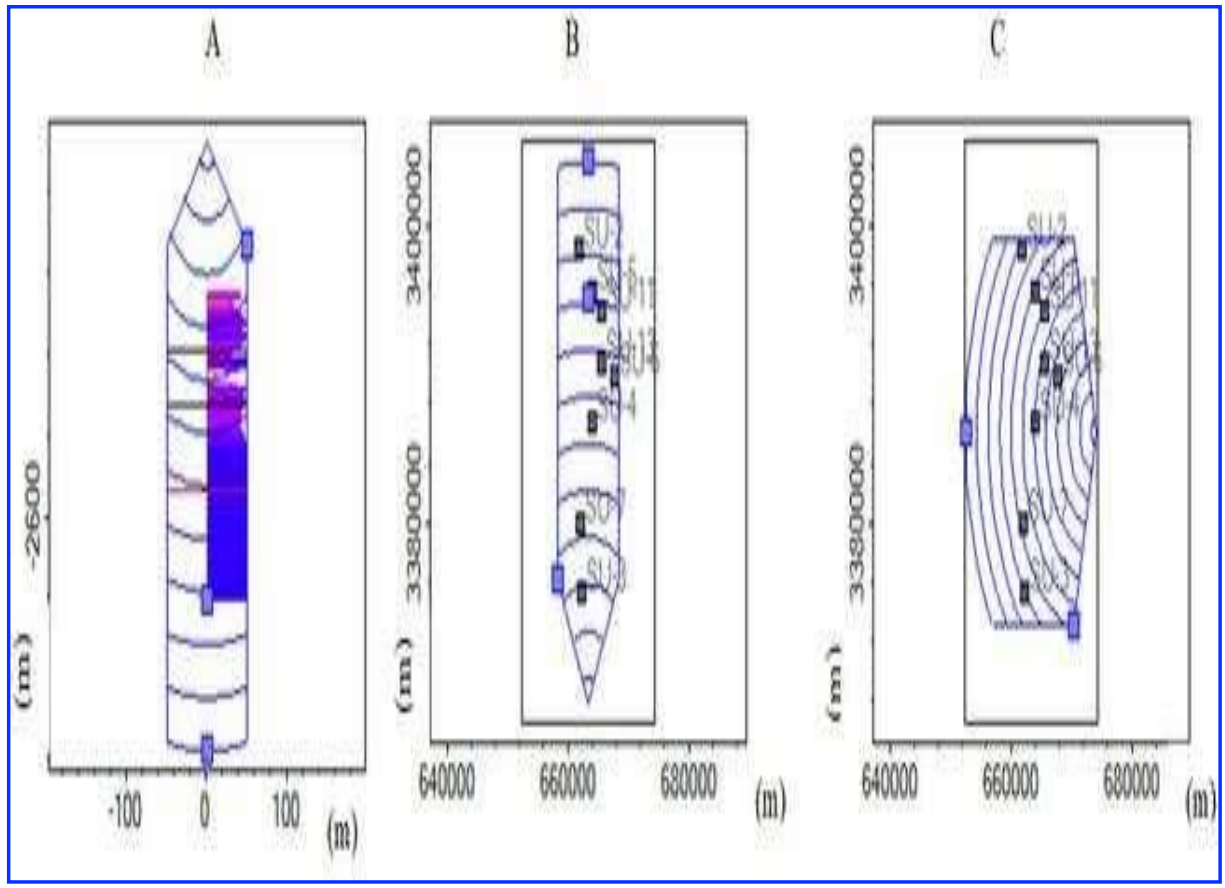

Fig. 10. A. Vertical direction; B: major direction and C: minor direction of the Nahr Umr Formation 


\subsubsection{Data transformation}

Large deviations from stationery and normality cause problems, so it is important to start looking at histogram to check normality of data. (Bohling, 2007). If the data has high deviation from normality, it must be transformed to normality to remove some skewed from data. (Fig. 11) shows the histogram of effective porosity before transformation and after transformation to the normal score for units B1, B2, C1, and C2. (Fig. 12) shows the histogram of water saturation before transformation and after transformation to the normal score for units B1, B2, C1, and C2.

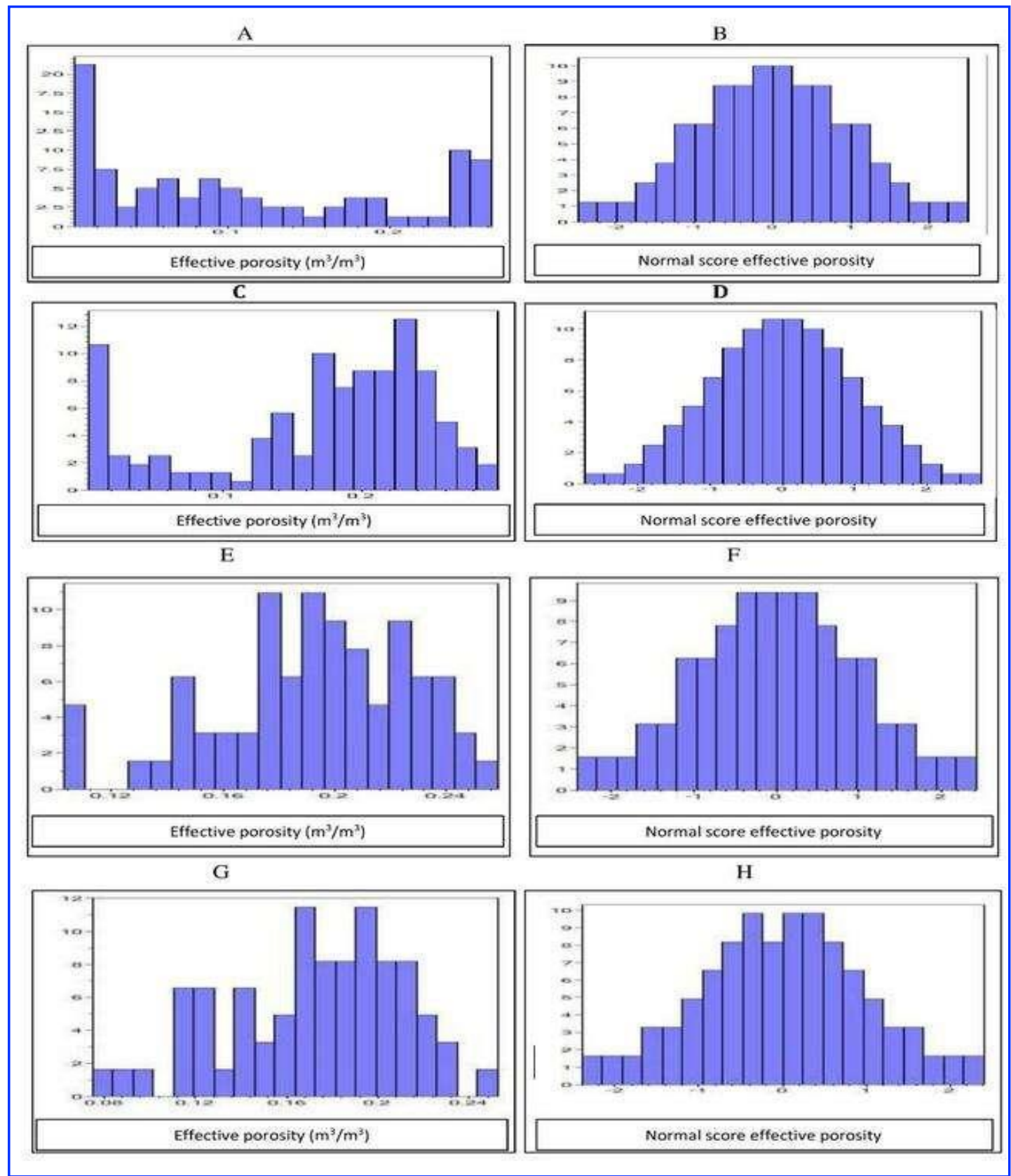

Fig. 11. A: Effective porosity for unit B1 before transformation, B: Effective porosity for unit B1 after transformation, C: Effective porosity for unit B2 before transformation, D: Effective porosity for unit B2 after transformation, E: Effective porosity for unit $\mathrm{C} 1$ before transformation, F: Effective porosity for unit $\mathrm{C} 1$ after transformation, G: Effective porosity for unit $\mathrm{C} 2$ before transformation, and $\mathrm{H}$ : Effective porosity for unit $\mathrm{C} 2$ after transformation 


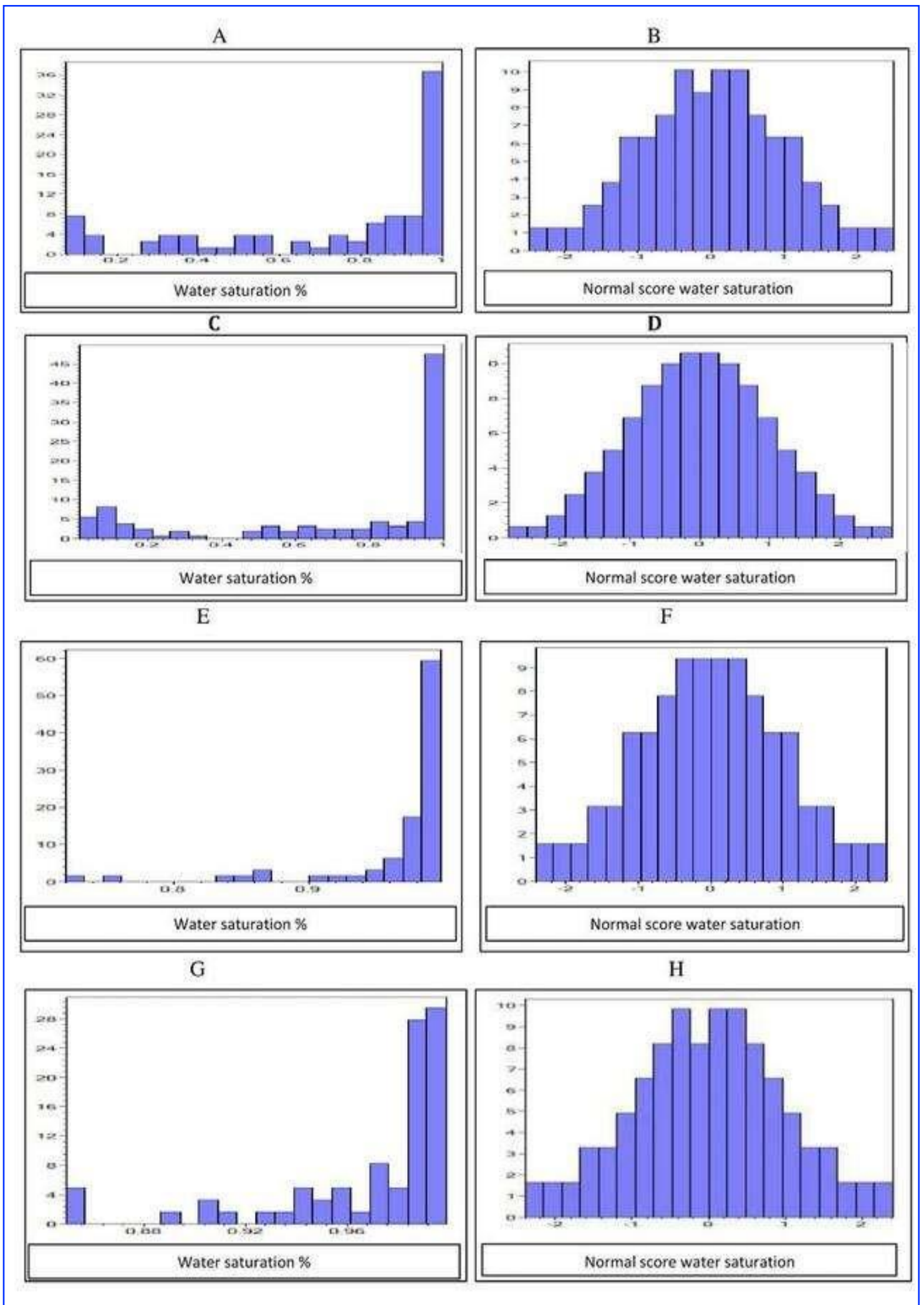

Fig. 12. A: Water saturation for unit B1 before transformation, $B$ : Water saturation for unit $B 1$ after transformation, C: Water saturation for unit B2 before transformation, D: Water saturation for unit B2 after transformation, E: Water saturation for unit $\mathrm{C} 1$ before transformation, $\mathrm{F}$ : Water saturation for unit $\mathrm{C} 1$ after transformation, G: Water saturation for unit $\mathrm{C} 2$ before transformation, and $\mathrm{H}$ : Water saturation for unit $\mathrm{C} 2$ after transformation 


\section{Results}

\subsection{Fitting Experimental Variogram}

Experimental variogram is calculated for vertical and horizontal direction, while all direction must be considered in the variogram to comprehend the behavior of the variogram, therefore the experimental variogram must fit with the specific positive definite functions such as gussian, exponential, and spherical variogram models. In this study, the experimental variogram shows high fitting with Spherical model after examining the models that are provided by the simulator. The experimental variograms in major and minor directions are shown in Figs.13-16. Figs. the experimental variograms which are calculated in horizontal direction (major and minor) is fit with spherical model which is provided by simulator. Therefore, spherical model is chosen to predict the properties in all directions.

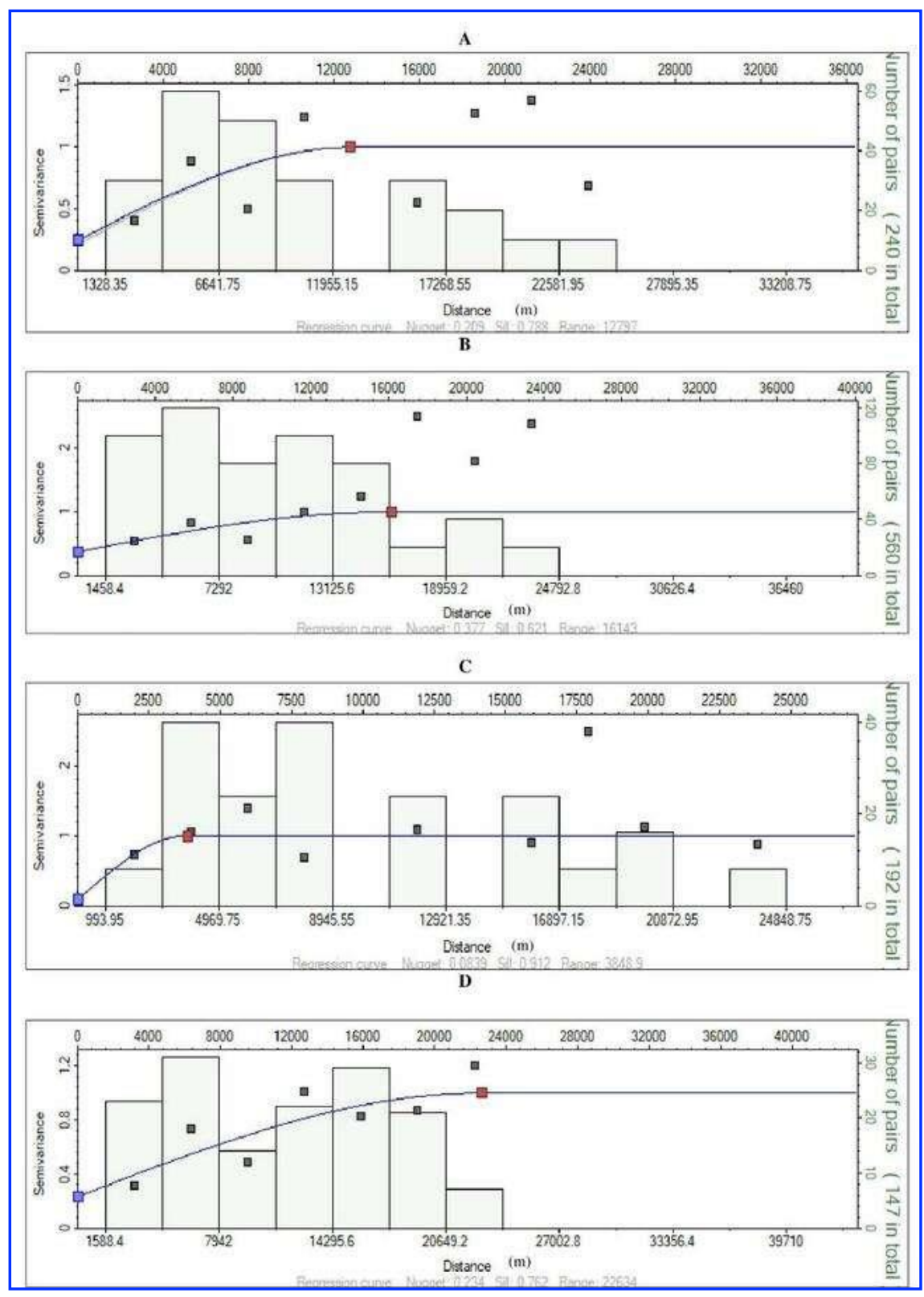

Fig. 13. A: Effective porosity variogram of unit B1 for major direction, B: Effective porosity variogram of unit $\mathrm{B} 2$ for major direction, $\mathrm{C}$ : Effective porosity variogram of unit $\mathrm{C} 1$ for major direction, and D: Effective porosity variogram of unit $\mathrm{C} 2$ for major direction 


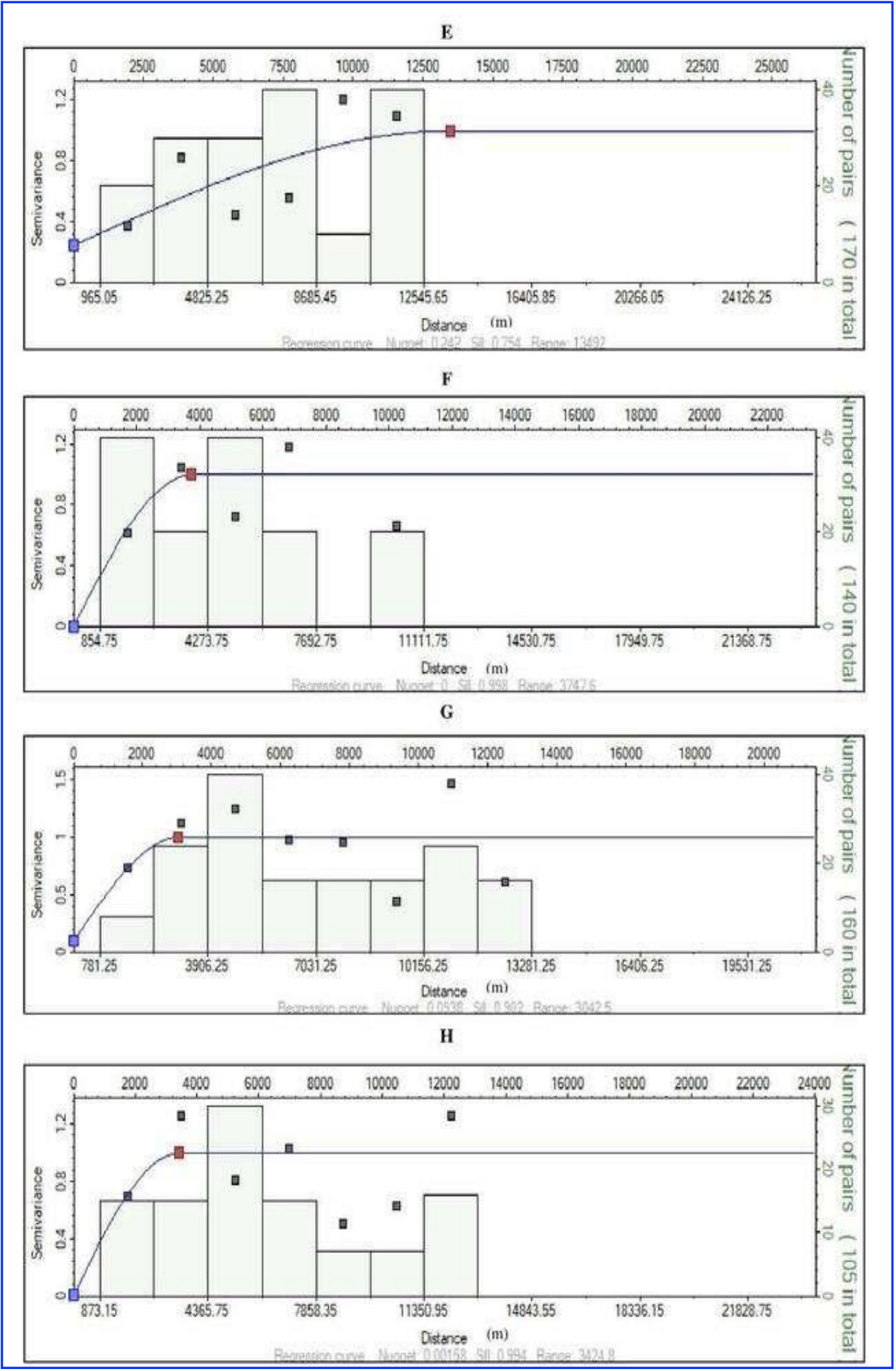

Fig. 14. E: Effective porosity variogram of unit B1 for minor direction, F: Effective porosity variogram of unit B2 for minor direction, G: Effective porosity variogram of unit C1 for minor direction, and H: Effective porosity variogram of unit $\mathrm{C} 2$ for minor direction 


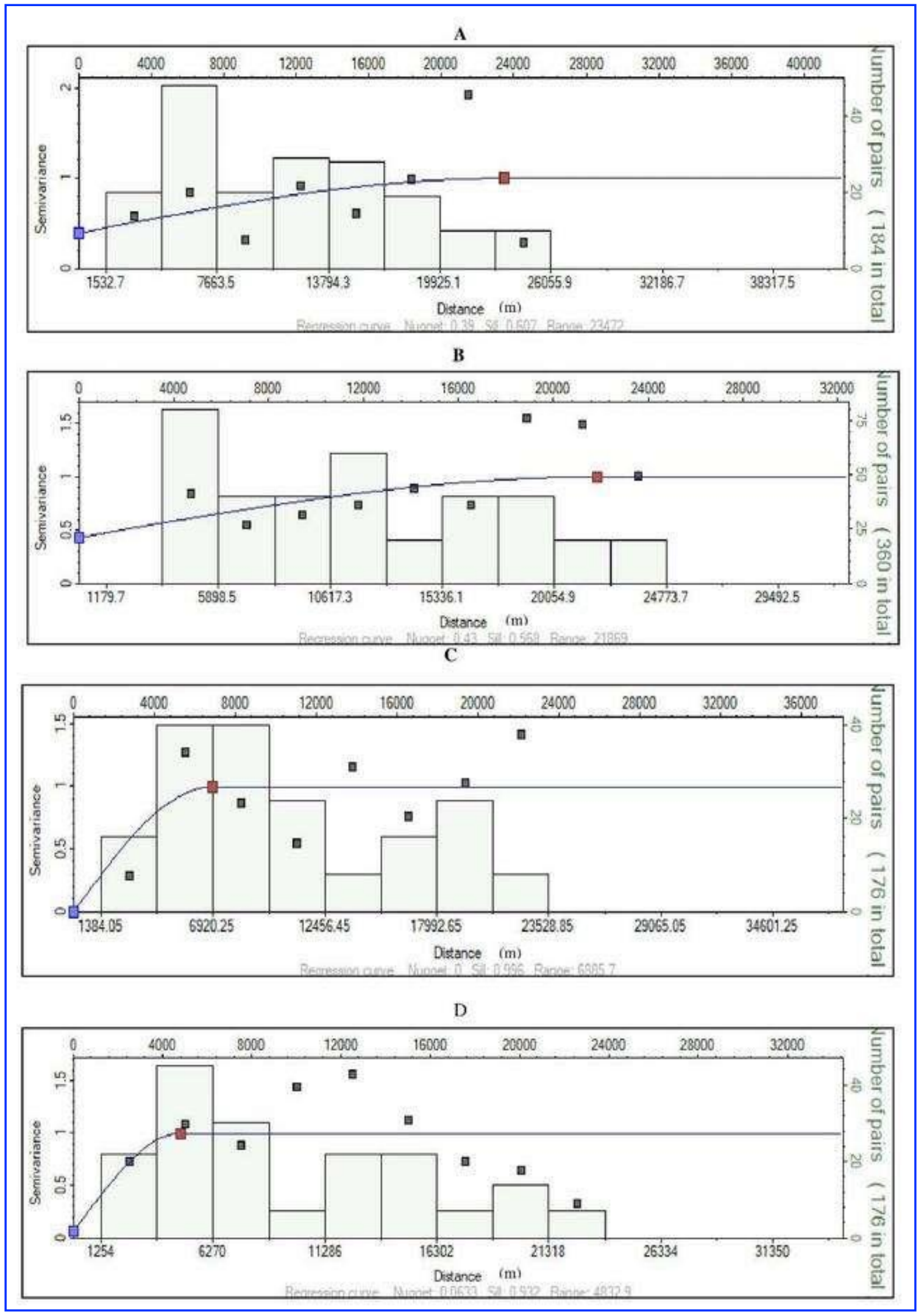

Fig. 15. A: Water saturation variogram of unit B1 for major direction, B: Water saturation variogram of unit B2 for major direction, $\mathrm{C}$ : Water saturation variogram of unit $\mathrm{C} 1$ for major direction, and $\mathrm{D}$ : Water saturation variogram of unit $\mathrm{C} 2$ for major direction 


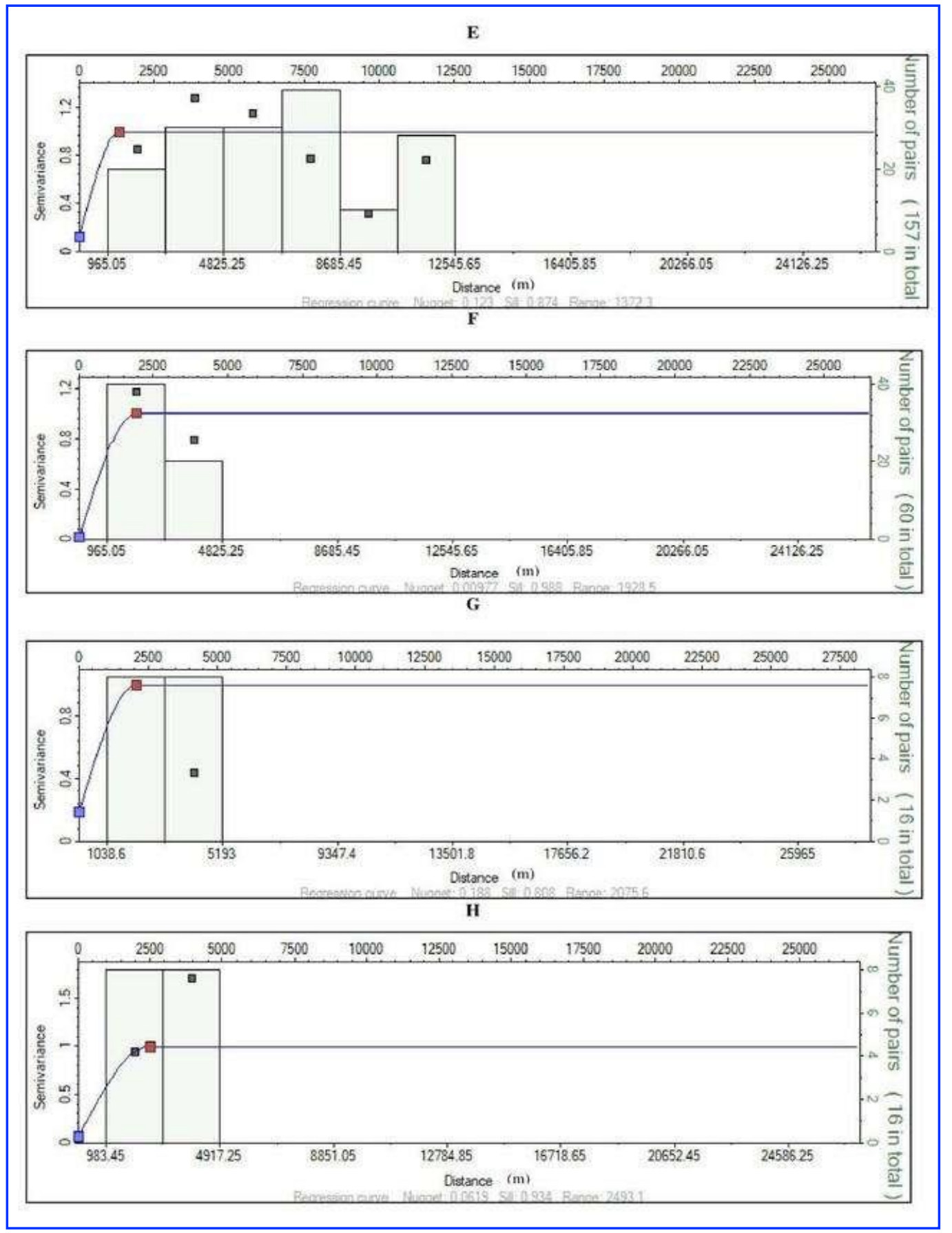

Fig. 16. E: Water saturation variogram of unit $B 1$ for minor direction, $F$ : Water saturation variogram of unit $B 2$ for minor direction, $\mathrm{G}$ : Water saturation variogram of unit $\mathrm{C} 1$ for minor direction, and $\mathrm{H}$ : Water saturation variogram of unit $\mathrm{C} 2$ for minor direction

\subsection{Petrophysical Model}

Well log data provides precise information for the water saturation and effective porosity that are obtained from computer processing interpretation to construct petrophysical models in this study. Sequential Gaussian Algorithm are used to distribute effective porosity and water saturation. Water saturation and effective porosity models are shown in Fig.17 to Fig.20. Effective porosity and water saturation ranges are shown in Table 1. Effective porosity of unit B1 is low in some wells (Su-9, Su-4, Su-14) because in these wells, the sand is overlapped with shale (Fig .17). Effective porosity of unit B2 increases toward Su-3 and Su-7, and decreases toward Su-2 (Fig.17). A good porosity in unit C1 
especially in the middle of the field toward wells (Su-14, Su-4, Su-9, and Su-7) (Fig.18). Effective porosity of unit $\mathrm{C} 2$ is good in most of wells especially in the middle of the field (Fig.18). Water saturation of the unit B1 is high in large parts of this unit, so it contains a small amount of oil (Fig.19), unit B2 is considered the main reservoir because it contains the most amount of oil (Fig.19). the units $\mathrm{C} 1$ and $\mathrm{C} 2$ are considered nonreservoir because they are highly saturated with water. (Fig. 20).

Table 1. Effective porosity and water saturation ranges for each unit

\begin{tabular}{|c|c|c|c|c|}
\hline Unit & $\begin{array}{l}\text { Effective } \\
\text { porosity } \\
\text { minimum } \\
\text { value\% }\end{array}$ & $\begin{array}{c}\text { Effective } \\
\text { porosity } \\
\text { maximum } \\
\text { value \% }\end{array}$ & $\begin{array}{c}\text { Water } \\
\text { saturation } \\
\text { minimum } \\
\text { value\% }\end{array}$ & $\begin{array}{c}\text { Water } \\
\text { saturation } \\
\text { maximum } \\
\text { value\% }\end{array}$ \\
\hline B1 & 0.046 & 0.2619 & 0.0744 & 0.9965 \\
\hline B2 & 0.035 & 0.2974 & 0.06 & 0.9967 \\
\hline $\mathrm{C} 1$ & 0.1026 & 0.2582 & 0.7196 & 0.9967 \\
\hline $\mathrm{C} 2$ & 0.0747 & 0.2522 & 0.84947 & 0.9987 \\
\hline
\end{tabular}

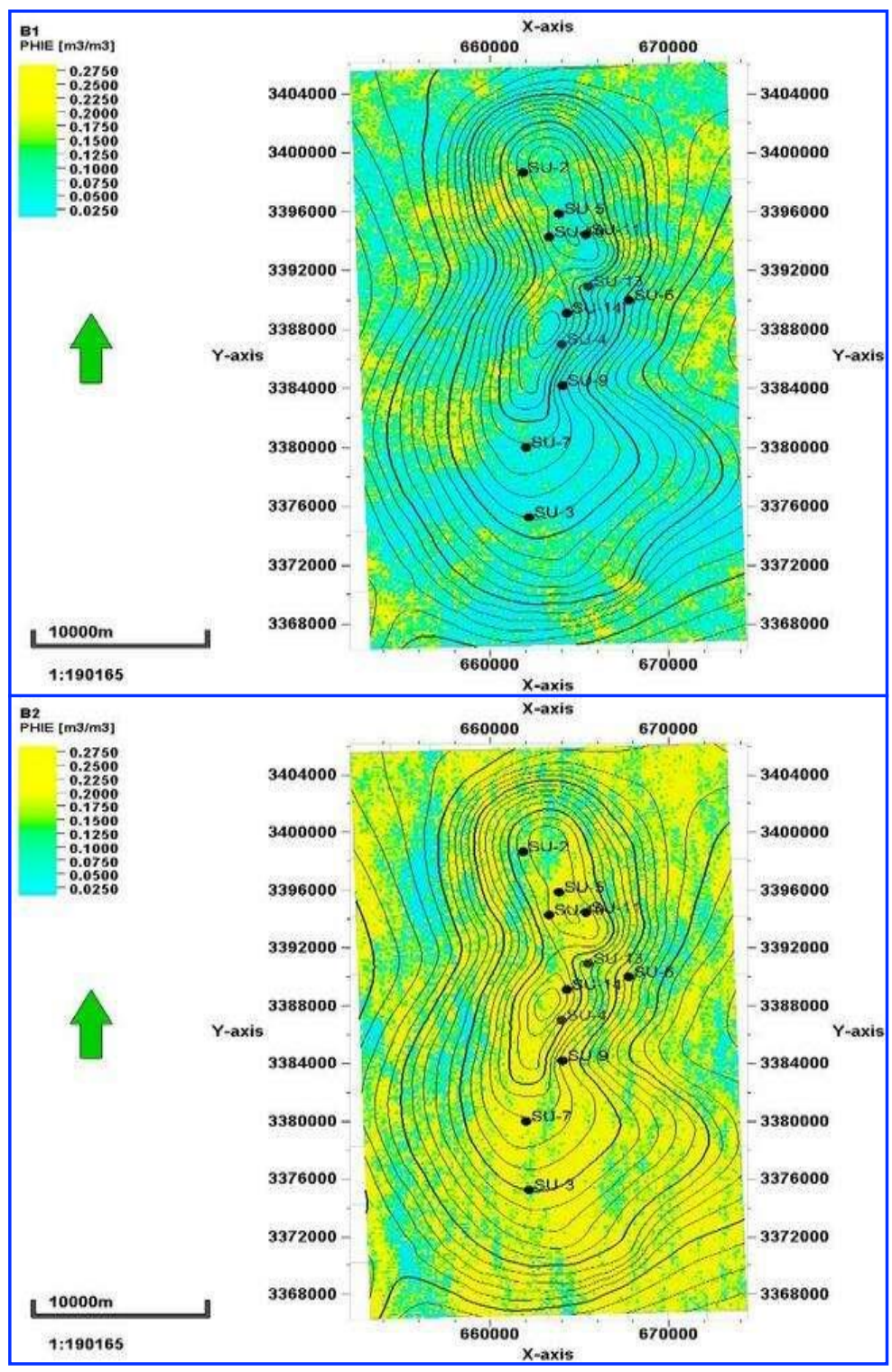

Fig. 17. Effective porosity model of unit B1 and B2 


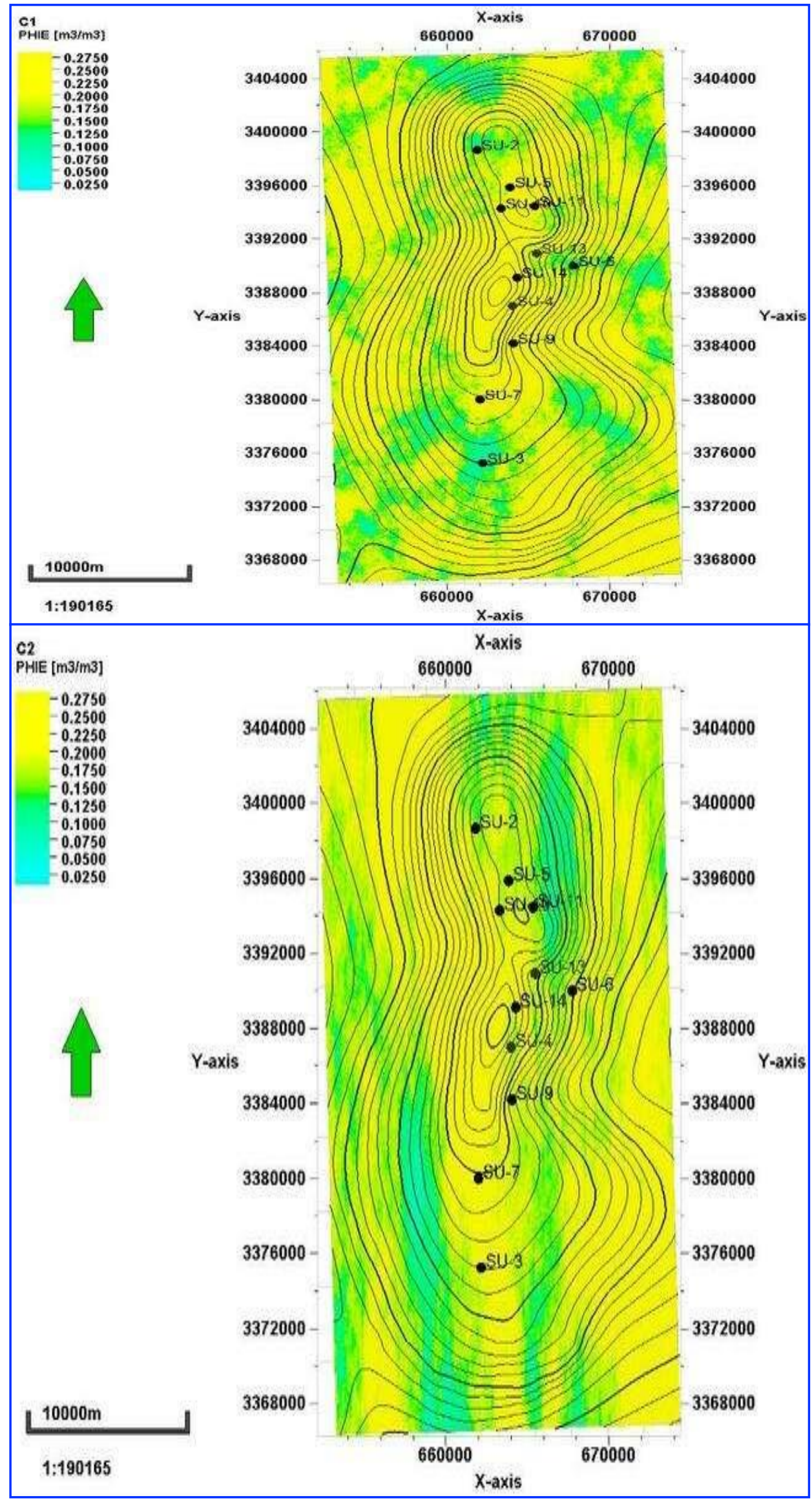

Fig.18. Effective porosity model of unit $\mathrm{C} 1$ and $\mathrm{C} 2$ 


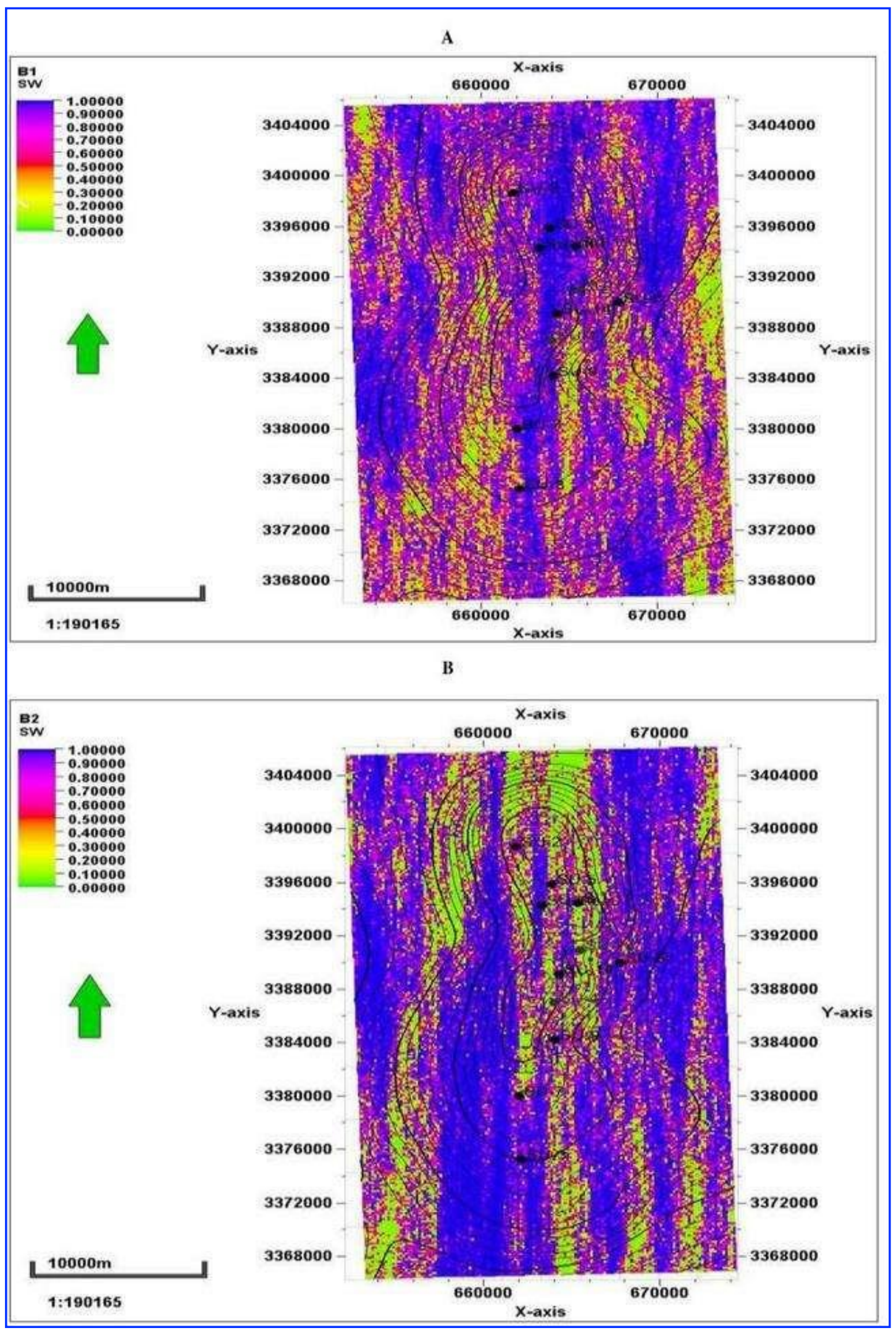

Fig. 19. Water saturation model of unit $B 1$ and $B 2$ 


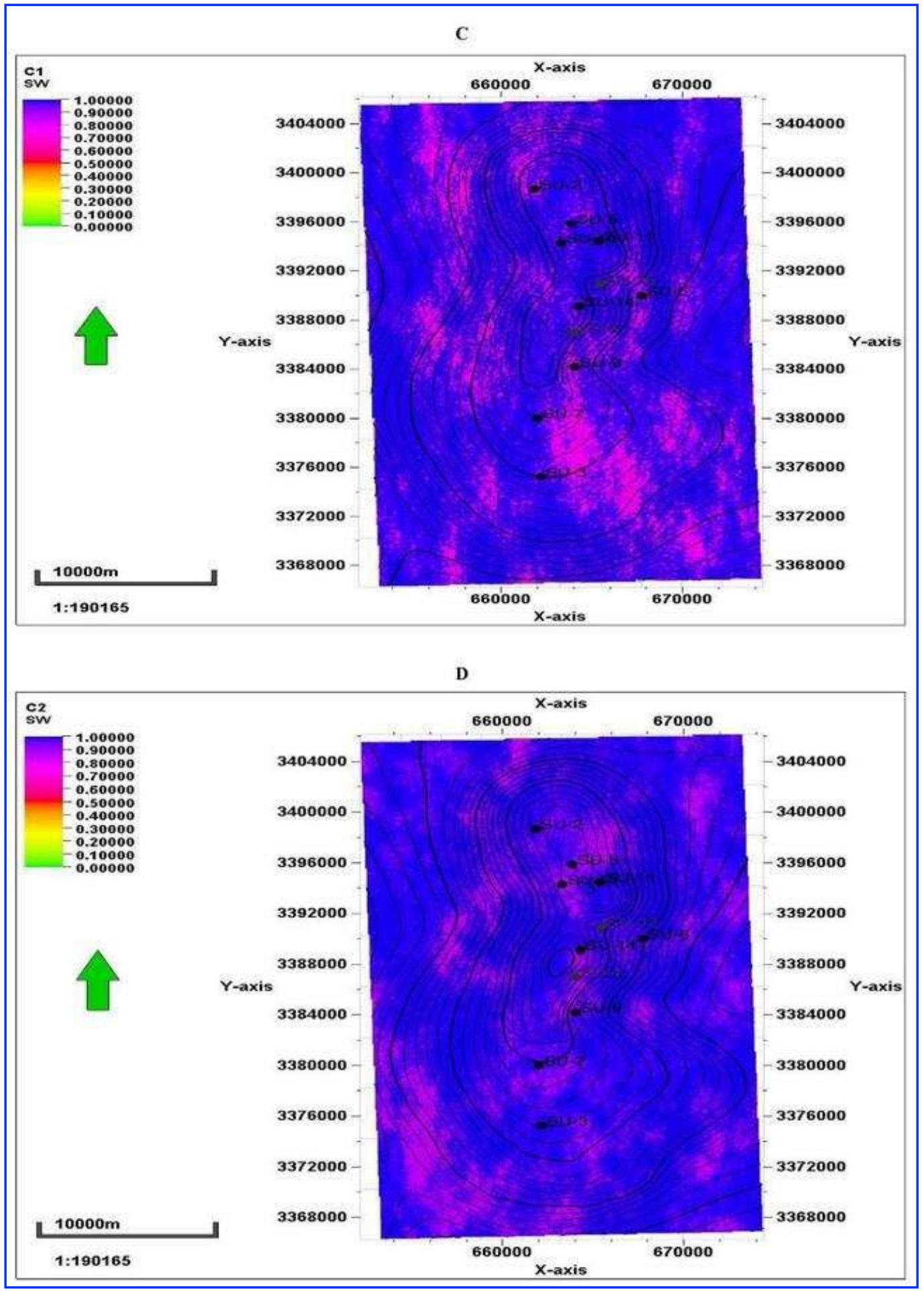

Fig. 20. Water saturation model of unit $\mathrm{C} 1$ and $\mathrm{C} 2$

\section{Conclusions}

- The Nahr Umr Formation in Subba oil field is composed of two domes, where the south dome is larger than the north dome as noticed from the structural model

- The petrophysical properties improved toward the north of the field.

- The histogram of water saturation shows high skewed, this may belong to the uncertainty in parameters of Archie's equation which was used to calculate water saturation, these parameters are $\mathrm{m}$ (Porosity exponent) and $\mathrm{n}$ (Saturation exponent).

- Unit B2 is divide into layers more than other units because it shows high heterogeneity. 
- The spherical variogram model is suitable for distribution the petrophysical properties because it is fitting with experimental variogram that is calculated based on data of well logs.

- The main reservoir units are B2 and B1 because they contain oil, where B2 unit has the most amount of oil, while $\mathrm{C} 1$ and $\mathrm{C} 2$ units are highly saturated with water.

- The higher structural depths of the field represent the reservoir because it contains oil mainly in unit B2 and a small amount of oil in unit B1.

- Although the lower parts of the formation $(\mathrm{C} 1$ and $\mathrm{C} 2)$ have good effective porosity, they are considered non reservoir units because they are highly saturated with oil.

- There is some uncertainty in petrophysical distribution in some parts of the field especially in west direction toward the edge of the field because of lacking of the drilling wells in these parts where most wells lay in the middle of the field.

\section{Acknowledgements}

The authors are very grateful to the Editor in Chief Prof. Dr. Salih M. Awadh, the Secretary of Journal Mr. Samir R. Hijab. and the Technical Editors for their great efforts and valuable comments.

\section{References}

Abraham, A. B., Evans, A. B., Thomposon, B. E., 2019. Analysis of spatial distribution pattern of reservoir petrophysical properties for horizontal well performance evolution-A case study of reservoir $\mathrm{x}$. The Open Petroleum Engineering Journal, 12(1), 1-13.

Al - Dabbas, M. A., Al-Jassim, J. A., Qaradaghi, A.I., 2012. Siliciclastic deposit of the Nahr Umr Formation, sedimentological and depositional environment studies, central and southern Iraq. Arabian Journal of Geosciences, 6(12), 4771-4783.

Alghanemy, G. C., Mahdi, T. A., 2020.Geological model of Hartha Formation in Majnoon oil field, southern Iraq. Iraqi Geological Journal, 53(1A), 48-57.

Al-Khazraji, A. K., Shuker, M. T., 2015. Optimal field development of immature clastic heterogeneous Brownfield with water drive: Subba Field, South Iraq case study. In SPE North Africa Technical Conference and Exhibition. Society of Petroleum Engineers.

Altameemi, A. M. H., Alzaidy, A., 2018. Geological modeling using petrel software for Mishrif Formation in Noor oil field, southeastern Iraq. Iraqi Journal of Science, 59(3C), 1600-1613.

Anadarko, 2009. Reservoir Study for Subba Oil Field, Nahr Umr Reservoir.

Amanipoor, H., Ghafoori, M., Lashkaripour, G. R., 2013. The application of geostatistical methods to prepare the 3D petrophysical model of oil reservoir. Open Journal of Geology, 3, 7-18.

Bohling, G., 2007. Introduction to Geostatistics in Hydro geophysics: Theory, Methods, and Modelling. Boise State University, Boise, Idaho.

Cannon, S., 2018. Reservoir Modelling. First ed. UK: John Wiley \& Sons Ltd

Chen, Z., 2007. Reservoir simulation: mathematical techniques in oil recovery. Philadelphia. Society for Industrial and applied Mathematics.

Exploration Oil Company (EOC), 2014. Geological Assessment Study of Subba Field

Ezekwe, N., 2010. Petroleum reservoir engineering practice. First ed. USA: Pearson Education

Faisal, M. J., Mahdi, T. A., 2020. Geological model of Mauddud Formation in Badra Oilfield. Iraqi Geological Journal, 53 (1A), 58-67.

Jaber, A. K., Shuker, M. T., 2014. Integrated petrophysical evaluation of a heterogeneous shaly-sand reservoir: a case study in Nahr Umr formation-Subba giant oil field, Iraq. Research Journal of applied Sciences, Engineering and Technology, 8(24), 2388-2402.

Iraqi National Oil Company (INOC), 1979. Geological Evaluation Study for Subba Oil Field,

Jreou, G., 2013. A preliminary study to evaluate Mishrif carbonate reservoir of Nasiriya oil field. International Journal of Engineering \& Technology, 13(05), 69-82.

Kouoh, J. J., Dicoum, E. M., 2019. Evaluating interpolation methods by geostatistical modeling of the Douala oil field porosity data (Cameroon). Geoinformatics \& Geostatistical: An overview, 7(1), 1-10.

Nasser, M. E., Al-Jawed, S. N., Hassan, M. F., 2017. Geological modeling for Yamama Formation in Abu Amood oil field. Iraqi Journal of Science, 58(2C), 1051-1068.

Pyrcz, M. J., Deutsch, C. V., 2014. Geostatistical reservoir modeling. Second ed. USA: Oxford university press.

Qiu, W. Y., Kelkar, M. G., 1995. Simulation of geological models using multipoint histogram. In SPE Annual Technical Conference and Exhibition. Society of Petroleum Engineers, 771-780

Rahimi, M., Riahi, M. A., 2020. Static reservoir modeling using geostatistics method: a case study of the Sarvak Formation in an offshore oilfield. Carbonates and Evaporites, 35(62), 62. 
Sahin, A., Ghori, S. G., Ali, A. Z., El-Sahn, H. F., Hassan, H. M., Al-Sanounah, A., 1998. Geological controls of variograms in a complex carbonate reservoir, Eastern province, Saudi Arabia. Mathematical Geology, 30(3), 309-322.

Schlumberger, 2013. Petrel technical Manual.

South Oil Company, 2008. Computer processing interpretation results (CPI) for wells and final well reports.

Vendrusculo, L. G., Magalhães, P. S. G., Vieira, S. R., Carvalho, J. R. P. D., 2004. Computational system for geostatistical analysis. Scientia Agricola, 61(1), 100-107.

Viera, M. A. D., Erdely, A., del Valle García, R., Kerdan, T., Mendoza-Torres, F., 2017. Geostatistical prediction of reservoir petrophysical properties by Copula based dependence models between seismic attributes and petrophysical properties. Science and Engineering, 90(91), 112-123.

Walker R.G., James N. P., 1992. Facies Models Response to Sea Level Change. Second ed. Canada: Geological Association of Canada.

Zabeel, K. H., 2017. Facial diffusion study for Nahr Umr Formation in Subba Field using well logs. Journal of Petroleum Research \& Studies. 